\title{
THE ROLES OF JOB AUTONOMY AND SELF-EFFICACY TO IMPROVE ACADEMICS' WORK-LIFE BALANCE
}

\author{
Siti Khadijah Zainal Badri ${ }^{* *}$ and Siti Aisyah Panatik ${ }^{2}$ \\ ${ }^{I}$ Division of Organisational and Applied Psychology, Business School, Faculty of Arts \\ and Social Sciences, The University of Nottingham, 43500 Semenyih, Selangor, Malaysia \\ ${ }^{2}$ School of Psychology, Faculty of Human Resource and Development, \\ Universiti Teknologi Malaysia, 81300 Skudai, Johor, Malaysia \\ *Corresponding author: SitiKhadijah.Zainal@nottingham.edu.my
}

Published online: 7 December 2020

To cite this article: Badri, S.K.Z. \& Panatik, S.A. (2020). The roles of job autonomy and self-efficacy to improve academics' work-life balance. Asian Academy of Management Journal, 25(2), 85-108. https://doi.org/10.21315/aamj2020.25.2.4

To link to this article: https://doi.org/10.21315/aamj2020.25.2.4

\begin{abstract}
Discussion on workers' work-life balance has been ongoing since the 1980s. However, less is known about work-life balance amongst university academics especially on the role of job autonomy and self-efficacy in influencing it. The current paper investigates the influence of job autonomy towards academics' work-life balance. Also, it examines the role of self-efficacy as a moderator in between this relationship. This study employed a quantitative method using the cross-sectional design using data on 307 responses to test these propositions. Using AMOS 23 and SPSS23, we established evidences on the positive influence of job autonomy towards academics' work-life balance. That is, high job autonomy linked to higher work-to-family enrichment and lesser work-to-family conflict occurrences. Besides, work-to-family enrichment was found higher when self-efficacy level was high, confirming the moderating role of self-efficacy. This study contributes to a greater understanding on the influence of both job autonomy and self-efficacy towards academics' work-life balance in terms of enrichment and conflict occurrences. It also affirms the constructive effects of self-efficacy to enhance the relationship between job autonomy and work-to-family enrichment. Findings from this study may be used to assist various human resource practitioners, researchers, and higher education institutions to build relevant policies to further support sustainable work-life balance practices within educational institutions.
\end{abstract}

Keyword: self-efficacy, job autonomy, work-to-family conflict, work-to-family enrichment, academics

(C) Asian Academy of Management and Penerbit Universiti Sains Malaysia, 2020. This work is licensed under the terms of the Creative Commons Attribution (CC BY) (http://creativecommons. org/licenses/by/4.0/). 


\section{INTRODUCTION}

Over the years, there has been an increasing concern over employees' work-life balance. Work-life balance is a continuum of life concerning multi interactions between various domains, commonly emphasising on work and family lives (Greenhaus \& Beutell, 1985). Prior studies have emphasised the needs of having a balanced work and family as a crucial element for individual's overall satisfaction and health (Choi \& Kim, 2017; Haar et al., 2014). The inter-relation between work and family has been interchangeably discussed in a few different keywords such as work-family conflict (Greenhaus \& Beutell, 1985), work-family facilitation (Proost et al., 2010), work-family enrichment (Friedman \& Greenhaus, 2000), and work-family interference, among others. Debates on this topic has been skewed into positive and negative notions. The positive notion believes that participating in multiple roles can be mutually beneficial (Greenhaus \& Powell, 2006), pointing to the possibility that work and family can act as an "ally". Whilst the latter denotes that engaging in multiple domains are conflicting, thus resulting in a higher likelihood for inter-domains conflict to occur (Greenhaus \& Beutell, 1985).

Prior research has suggested that employees' condition of work-life balance can be influenced by the amount of control they received at work (Ng et al., 2017). Work control or job autonomy refers to the degree of flexibility granted to the employee in managing their tasks (Haar et al., 2019). The provision of job autonomy has been reported in the past to manage their work and life aspects better (Haar et al., 2019). Acquiring job autonomy is associated with a range of positive consequences such as higher creativity and greater positive goal determination, which are important aspects to maintain employees' motivation, engagement, and counterbalance job strain (Li et al., 2018; Nauta et al., 2010). However, there has been a dearth of knowledge on how job autonomy influences academics' work-life balance. Despite the academic population well known for their access to a greater job autonomy at work, studies are still reporting likeliness of this population to suffer from imbalance terms of high work-family conflict (Hogan, 2015; Kinman $\&$ Jones, 2008). As the academic staff have little autonomy over the amount of job they need to perform (Lyons \& Ingersoll, 2010), this may cancel the positive benefit from having a flexible working and impedes their work-life balance.

Maintaining a balanced work and life is highly influenced by dispositional or individual trait such as self-efficacy. Self-efficacy enables an individual to exert control over their thought, behaviour, and actions (Bandura, 1997). This influences individual reaction to event or behaviour (Einar \& Sidsel, 2010). Those with higher self-efficacy are likely to display a higher ability to control their thoughts and actions, thus leading to more positive consequences such as higher satisfaction, 
superior performance and better decision making at work (Guarnaccia et al., 2018; Sogolitapeh \& Razmi, 2011). However, whilst the body of literature continues to be plagued with researches on self-efficacy, empirical evidence that investigates the moderating role of self-efficacy between the relationship of job autonomy with work-life balance remains limited among academics' population.

Henceforth this paper's objective is two-fold. First is to investigate how job autonomy influences academic's work-life balance which this study operationalises into negative and positive constructs i.e., work-to-family conflict (negative) and work-to-family enrichment (positive). Second is to examine the moderating role of self-efficacy as a moderator between these relationships. Using the conservation of resource (COR) theory as its underlying framework, this paper adds to the current literature by strengthening the theoretical and practical understanding of the relationship between job autonomy and self-efficacy towards work-life balance within the academic setting. Also, it contributes to assisting future policy development and identification of family-related policy to strengthen the higher education.

One of the progressing issues faced by academics in higher education institutions (HEIs) is a challenge to attain a good work and life balance (Kinman \& Jones, 2008). In Malaysia, higher education is one of the important service sectors which contributed around 5.8 percent of the country economic growth in the year 2018 with 67,616 registered academics spread across the nation (Ministry of Higher Education, 2019). Whilst academics are widely acknowledged as an important asset to HEIs, and despite high job autonomy being a substance of the academic profession (Badri, 2019), health and wellbeing issues keep emerging (Clarke et al., 2015). A recent review by Le et al. (2020) focusing on work-life balance challenge in Asia region has emphasised that the spike in demands and high workload in academia-industry have resulted in academics to struggle juggling their work and life commitments. According to Le et al. (2020), economic transformation and commercialisation of HEIs have led to a massive reformation in the higher education system changing the landscape to be even more stressful than before. Issues such as a greater requirement for research output and student's enrolment on top of high teaching and administrative workload has developed barriers for academics to maintain their work-life balance. Within the Malaysian setting, a study by Panatik et al. (2012) has mentioned how intense demands and higher workload has changed the higher education landscape causing many academics to encounter higher level of work-family conflict. It was reported that the conflicting work and family responsibilities were associated with the increase of behaviour, somatic, and cognitive stresses symptoms among them. 
Similarly, Noor (2011) discovered that poor work-life balance is among factors that causes higher intention to quit among this occupational group. Overburdened by the immense expectation to perform well in various job aspects ranging from teaching, researching, and administrative, they have been experiencing higher interrole conflict, thus leading to higher dissatisfaction when rating their work (Badri, 2019), that may cause higher absenteeism and poor job performance problems (Husin et al., 2018). Meanwhile, lack of organisational support and overworking continue to underscore in prior research (Nasurdin \& O'Driscoll, 2011), with a greater propensity of female academics found to experience conflicting work and family demands due to strong gender role expectation especially in Asia (Achour \& Boerhannoeddin, 2011). Despite academics' privilege to practice self-governing to enhance their engagement and retention at work (Richman et al., 2008), higher intention to quit still being discovered (Clarke et al., 2015; Panatik et al., 2012). More importantly, the changing landscape and evolving HEI environment warrant for newer investigation on academics' work-life balance (i.e., Le et al., 2020) and how the practice of work autonomy may affect their work and life conditions.

Henceforth, driven by these problems, we aim to investigate academics' worklife balance condition and how it may be influenced by the provision of work autonomy and self-efficacy.

\section{LITERATURE REVIEW}

\section{Job Autonomy}

Job autonomy is defined as freedom given to workers in actively taking control throughout the completion of their job (Hackman \& Oldham, 1980). It describes the extent in which one job permits freedom, independence, and discretion to work schedule, making a decision and selecting an appropriate method to be used in performing tasks (Morgeson et al., 2005; Frederick et al., 2005). Past researches have linked job autonomy as one important job characteristic in designing a safer and supportive workplace (Parker et al., 2001). Based on Job-demands Control model, the lack of autonomy in presence of high workload may wear out the employees' resources and lead to various problems such as low retention, burnout, emotional exhaustion, workplace bullying, and declining of employee wellbeing, among others (Baillien et al., 2011; De Jonge \& Schaufeli, 1999). An array of empirical discovered the positive influence of job autonomy towards employee wellbeing and motivation, however, the low level of job autonomy is associated with deleterious effects (Kubicek et al., 2017). 


\section{Work-life Balance}

The changing landscape of the workforce and more women venturing into a professional setting has contributed to the ascending of work-life balance topic. As aforementioned, the notion in work and life discussion has been hugely divided into two areas - negative and positive. Work-to-family conflict was one among few negative constructs defined as "a form of inter-role conflict in which role pressures from work and family domains are mutually incompatible in some respects" (Greenhaus \& Beutell, 1985, p. 77). It emphasises on the conflict that occurs between work and family domains, which can be explained through the interference of time, strain, and behaviours caused by demanding situations from work towards family (Carlson et al., 2000). On the other hand, work-to-family enrichment was conceptualised by Greenhaus and Powell (2006) as "the extent to which experience in one work improves the quality of family role" (p. 72). It centralises on how participation in a role can benefit an individual through the enrichment experience towards another role which happened through the improvement of skills, knowledge, and resources from fulfilling a role (Greenhaus \& Powell, 2006).

Conflicts happening between work and life domains have been associated in the past research works with issues such as poor satisfaction, low performance, productivity, commitment, and absenteeism in the workplace (Reddy et al., 2010; Lingard et al., 2007). A huge body of literature has also established evidence on antecedents for this variable, for instance, working hours, supervisor support, organisational culture, and job characteristics among few others (Lingard et al., 2007; Beuregard \& Henry, 2009). Offering a family-responsive policy or childcare at the workplace have been generally found in the past to improve employees' work-life balance (Grover \& Crooker, 1995). However, the degree of work-life balance practice within the organisation may be varied. There is a considerable difference in terms of nature of the support given or help offered to the employee especially towards dual-earners family across different sectors (Crompton \& Lyonette, 2006). Other than organisational factors, the effectiveness of work-life balance policy is highly depending on individual factors. Studies have been suggesting that the outcome for work-life balance can be influenced by the degree of segmentation and perceived boundary control (Mellner et al., 2015). For instance, some individual might prefer to properly separate work and family, while others may prefer to balance their lives by integrating these two domains. 


\section{Self-efficacy}

Believing is an act which serves as a foundation for individual motivation, accomplishment, and wellbeing (Bandura, 1997). Self-efficacy refers to a set of belief in the ability to perform and influence any events that occur in lives (Bandura, 2010). It is a form of belief that enables an individual to exert control over their thought of action (Schwarzer, 1992). Perceived self-efficacy helps individual to cope with a series of positive and negative events such as failure, challenge in life, and even act as an innate drive to perform better (Bandura, 1982). From an organisational perspective, self-efficacy has been linked with increased appraisal effectiveness (Wood \& Marshall, 2008), reduction of counterproductive behaviour at work (Barbaranelli et al., 2019), greater employee resilience, and higher commitment and success (Ballout, 2009). A huge body of literature has also utilised self-efficacy as a potential moderator and mediator in explaining these organisational outcomes (Fitzgerald \& Schutte, 2010; Ballout, 2009; Wood \& Marshall, 2008). This includes investigating its moderating effect on occupational stress (Grau et al., 2001), workplace attitudes (O’Neill \& Mone, 1998), informationseeking effectiveness (Brown et al., 2001), and counterproductive work behaviour (Cretu \& Burcas, 2014).

\section{RESEARCH FRAMEWORK AND HYPOTHESIS}

\section{Underlying and Research Framework}

Many organisational theories have emphasised on the availability of a resource mostly something that could be seen when discussing human behaviour in the organisational behaviour perspective. However, can act of believing and taking control improve workers' condition of work-life balance? Based on conservation of resource theory (COR) (Hobfoll, 1989), motivation is the main driver to the act of maintaining, protecting, and pursuing. Operating based on two principles: (1) primacy of resource loss, and (2) resource investment, this theory states that losing resource is harmful, meanwhile gaining resource is helpful. The premise is those with higher resources are likely to receive more resources which an early indicator to a greater resource acquirement in future times. However, initial resource loss is an indicator that more resource will be misguided as it promotes in defensive attempt to protecting the remaining.

In respect to the current study, we theorise that a condition of low job autonomy is linked to a resource loss situation. Therefore, those at resource loss will experience higher work and family domains conflict due to the absence of resources in keeping 
work and family at good reciprocating state. Missing of the control causes a poor equilibrium in between the two spheres which consequently causes conflict arousal. In contrast, those with higher job autonomy are at advantage of resource gain. In such circumstance, the opportunity to take control over own job links to resource gain, thus resulting in ease of experience when juggling work and family domains. As resource gain promotes higher ownership (Hobfoll, 1989), it endorses a higher degree of involvement between work and family, thus subsequently increasing domains enrichment. Besides, the presence of a functional dispositional resource such as self-efficacy might strengthen the existing linkage between job autonomy and work-life balance constructs. Thus, self-efficacy works as an advocate to further improve the academic's condition of work and life. Our proposed framework is illustrated in the following Figure 1.

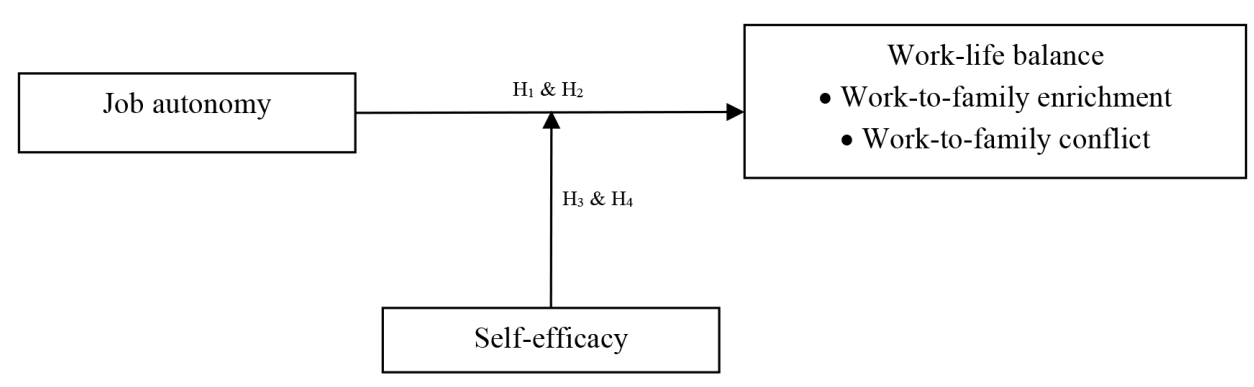

Figure 1. The diagram of the study framework

\section{Hypothesis Testing}

\section{Direct effects of job autonomy on work-life balance}

Prior findings suggested that those with higher job autonomy are likely to be more efficient and engaging suggesting a positive effect on worker performance (Sisodia \& Das, 2013). Empirical evidences have suggested that job autonomy influences workers' work and life condition but with mixed findings (Kelly et al., 2011; Greenhaus \& Powell, 2006). For instance, a study by Tement and Korunka (2015) found high job autonomy associated with greater work-family enrichment. Another study by Grotto and Lyness (2010) found that low job autonomy associates with higher work-family conflict. Therefore, we assume the greater degree of control at work or job autonomy will influence academics' work and life balance in two ways. First, high job autonomy increases work-family enrichment. While second, low autonomy results in higher work-family conflict. Henceforth, our first and second hypothesis are as the following. 
$\mathrm{H}_{1}$ : Job autonomy has a significant positive relationship with work-tofamily enrichment.

$\mathrm{H}_{2}$ : Job autonomy has a significant negative relationship with work-tofamily conflict.

\section{The moderating role of self-efficacy}

The concept of self-efficacy is recurrently employed in promoting academic teaching and learning behaviour in HEI (Klassen \& Chiu, 2010). It is one of the common topics relating to success and academic achievement (Wheately, 2005). Those with higher self-efficacy had greater resilience to adapt and thrive in a challenging environment (Mohamadi \& Hassan, 2012). It has been suggested that high self-efficacy is linked to higher educational goals and better interpersonal relationship with others. In a recent review by Hobfall et al. (2018) on re-visiting of COR, self-efficacy is acknowledged amongst one of the crossover resources. The presence of self-efficacy helps to thrust individual motivation and ability to selfexpand, thus, further improving the anticipating outcome. On this basis, we argue that high self-efficacy helps academic to thrive better in between job autonomy and work-life balance, in which, in the presence of higher self-efficacy, the degree of relationship between job autonomy and work-life balance constructs are further strengthened. As those with high self-efficacy has greater likeliness to put in more effort and perseverance (Zimmerman et al., 1992; Einar \& Sidsel, 2010), it extends the positive effect between job autonomy and work-family enrichment and subdues negative relationship of between job autonomy and work-family conflict.

$\mathrm{H}_{3}$ : Self-efficacy significantly moderates the relationship between job autonomy and work-to-family enrichment. As such, the relationship is high when job autonomy is high, compared to when job autonomy is low.

$\mathrm{H}_{4}$ : Self-efficacy significantly moderates the relationship between job autonomy and work-to-family conflict. As such, the relationship is lower when job autonomy is high, compared to when job autonomy is low.

\section{METHODOLOGY}

\section{Research Design}

This was a quantitative study with the use of a cross-sectional design. 


\section{Sampling Technique}

A total of 307 academic staff from five research status universities had participated in this research. Only academics staff from research universities were selected, as this research was particularly focusing on institutions offering flexible working policy. Also, we included only full-time academics with positions from lecturer and onwards. Tutors were excluded as they did not meet the criteria for this research. Samples were collected using a convenience sampling whereby emails of the potential respondents were retrieved from the universities' website and selected based on those who met the mentioned pre-requisites to be invited in this research.

\section{Procedure and Ethical Guidelines}

The survey was designed using Google's document application. All invitations were sent through email followed by a reminder sent after three weeks. Prior to commencing data collection, an approval to conduct research was obtained from Universiti Teknologi Malaysia (UTM) and the Ministry of Higher Education (MOHE). Information regarding the nature of the study and anonymity was briefed on the first page of the survey. All respondents were informed on their right to withdraw anytime during the data collection period.

\section{Pilot Study}

A pilot study was conducted to ensure good consistency of the instrument. The result suggested that all instruments for job autonomy, work-life balance constructs, and self-efficacy were higher than 0.70 , thus all items were retained in its original format during data collection.

\section{Instruments}

Job autonomy was measured using three items by the Job Diagnostic Survey (JDS) (Hackman \& Oldham, 1980). All items were scored with a 5-point Likert scale, ranging from 1 (strongly disagree) to 5 (strongly agree). Sample of an item is "I have very little freedom in deciding how the work is to be done". Work-life balance constructs were measured using the Work-family Enrichment (W-FE) scale by Carlson et al. (2006) and Work-family Conflict (W-FC) scale by Carlson et al. (2000). Both scales consisted of nine items which were rated from 1 (strongly disagree) to 5 (strongly agree). Samples of items are "The problem-solving behaviors I use in my job are not effective in resolving problems at home" for W-FC, and "My participation at work helps me to understand different viewpoints and this helps me be a better family member" for W-FE. This study measured self- 
efficacy using 10-items of general self-efficacy scale by Schwarzer and Jerusalem (1995). All items were rated from 1 (strongly disagree) to 5 (strongly agree). Sample of an item is "I can always manage to solve difficult problems if I try hard enough".

\section{Data Analysis}

Data and result analysis were handled using SPSS and AMOS version 24.

\section{RESULTS}

\section{Demographic Profile of the Respondents}

The demographic analysis summary is illustrated in Table 1. Findings revealed that most of the respondents were female with 173 respondents while male comprises 134 respondents. Majority of the respondents were Malays with 251 respondents, followed by Chinese ( 24 respondents), Indian ( 8 respondents) and other ethnicities (24 respondents). For marital status, most of the respondents were married with a total of 260 respondents. Only 37 were single, nine were divorced and one classified as others (i.e., windowed, separated). Academics in Universiti Putra Malaysia (UPM) have the highest participating rate with 85 respondents, followed by Universiti Teknologi Malaysia (UTM) with 78 respondents, Universiti Sains Malaysia (USM) with 60 respondents, Universiti Malaya (UM) with 49 respondents and lastly Universiti Kebangsaan Malaysia (UKM) with 35 respondents. In terms of job position, most of the academics were associate professors (158 respondents), followed by senior lecturers (62 respondents), professors (49 respondents), and lecturers (38 respondents). Majority of the respondents have job tenure below five years with 71 respondents, followed by $6-10$ years (62 respondents), 25 and above (56 respondents), 11-15 years (48 respondents), 16 to 20 years (45 respondents), and 21-24 years (25 respondents). 
Table 1

Demographic profile of the respondents

\begin{tabular}{|c|c|c|}
\hline Profile & & $f(\mathrm{n})$ \\
\hline \multirow[t]{2}{*}{ Gender } & Male & 173 \\
\hline & Female & 174 \\
\hline \multirow[t]{3}{*}{ Ethnicity } & Malay & 251 \\
\hline & Chinese & 24 \\
\hline & Indian & 8 \\
\hline \multirow[t]{4}{*}{ Marital status } & Married & 260 \\
\hline & Single & 37 \\
\hline & Divorced & 9 \\
\hline & Others & 1 \\
\hline \multirow[t]{5}{*}{ University } & UPM & 85 \\
\hline & UTM & 78 \\
\hline & USM & 60 \\
\hline & $\mathrm{UM}$ & 49 \\
\hline & UKM & 35 \\
\hline \multirow[t]{4}{*}{ Position } & Professor & 49 \\
\hline & Associate professor & 158 \\
\hline & Senior lecturer & 62 \\
\hline & Lecturer & 38 \\
\hline \multirow[t]{6}{*}{ Tenure } & Below 5 years & 71 \\
\hline & $6-10$ years & 62 \\
\hline & $11-15$ years & 48 \\
\hline & $16-20$ years & 45 \\
\hline & $21-24$ years & 25 \\
\hline & 25 years and above & 56 \\
\hline
\end{tabular}

Validity, Reliability, and Confirmatory Factor Analysis Result

All scales were validated before running hypothesis testing. Result for discriminant validity suggests that all $A V E$ and $C R$ values were higher than the suggested threshold of 0.50 (Hair et al., 2010). All scales satisfactorily met the Cronbach alpha threshold of 0.70 (Nunnally, 1978). Meanwhile, AVE for each construct is higher than the correlation value, suggesting good discriminant validity. Construct validity was executed using confirmatory factor analysis. The goodness of fit indexes for all constructs was acceptable meeting all the threshold with: (1) job 
autonomy, $\chi^{2}(\mathrm{n}=307)=73.03, p<0.001, \chi^{2} / \mathrm{df}=3.04, \mathrm{RMSEA}=0.08, \mathrm{RMR}=$ $0.02, \mathrm{CFI}=0.95, \mathrm{GFI}=0.98$; (2) work-to-family enrichment, $\chi^{2}(\mathrm{n}=307)=97.62$, $\left.p<0.001, \chi^{2} / \mathrm{df}=2.87, \mathrm{RMSEA}=0.07, \mathrm{RMR}=0.17, \mathrm{CFI}=0.93, \mathrm{GFI}=0.96\right)$; (3) work-to-family conflict, $\chi^{2}(\mathrm{n}=307)=58.92, p<0.001, \chi^{2} / \mathrm{df}=2.45$, RMSEA $=0.07, \mathrm{RMR}=0.03, \mathrm{CFI}=0.96, \mathrm{GFI}=0.95$; and (4) self-efficacy, $\chi^{2}(\mathrm{n}=307)=$ $0.828, p<0.001, \chi^{2} / \mathrm{df}=0.828, \mathrm{RMSEA}=0.00, \mathrm{RMR}=0.009, \mathrm{CFI}=1.00, \mathrm{GFI}$ $=0.99$.

Table 2

Validity and reliability of the scales

\begin{tabular}{|c|c|c|c|c|}
\hline \multirow[b]{2}{*}{ Construct } & \multirow[b]{2}{*}{ Items $^{* *}$} & \multicolumn{3}{|c|}{ Convergent validity } \\
\hline & & $\begin{array}{l}\text { Factor } \\
\text { loading }\end{array}$ & $\mathrm{AVE}^{\mathrm{a}}$ & $\mathrm{CR}^{\mathrm{b}}$ \\
\hline \multirow[t]{3}{*}{ Job autonomy } & $\begin{array}{l}\text { My job permits me to decide on my own how to } \\
\text { do my work }\end{array}$ & 0.83 & 0.61 & 0.83 \\
\hline & $\begin{array}{l}\text { My job gives me considerable opportunity for } \\
\text { independence and freedom in how I do the work }\end{array}$ & 0.87 & & \\
\hline & $\begin{array}{l}\text { My job denies me any chance to use my personal } \\
\text { initiative or judgment in carrying out the work }\end{array}$ & 0.64 & & \\
\hline \multirow[t]{8}{*}{ W-FE } & $\begin{array}{l}\text { My involvement in my works helps me to } \\
\text { understand different viewpoints and this helps me } \\
\text { be a better family member }\end{array}$ & 0.88 & 0.79 & 0.97 \\
\hline & $\begin{array}{l}\text { My involvement in my works helps me to gain } \\
\text { knowledge and this helps me be a better family } \\
\text { member }\end{array}$ & 0.88 & & \\
\hline & $\begin{array}{l}\text { My involvement in my works helps me acquire } \\
\text { skills and this helps me be a better family member }\end{array}$ & 0.91 & & \\
\hline & $\begin{array}{l}\text { My involvement in my works puts me in a } \\
\text { good mood and this helps me be a better family } \\
\text { member }\end{array}$ & 0.87 & & \\
\hline & $\begin{array}{l}\text { My involvement in my works makes me feel } \\
\text { happy and this helps me be a better family } \\
\text { member }\end{array}$ & 0.94 & & \\
\hline & $\begin{array}{l}\text { My involvement in my works makes me cheerful } \\
\text { and this helps me be a better family member }\end{array}$ & 0.93 & & \\
\hline & $\begin{array}{l}\text { My involvement in my works helps me feel } \\
\text { personally fulfilled and this helps me be a better } \\
\text { family member }\end{array}$ & 0.86 & & \\
\hline & $\begin{array}{l}\text { My involvement in my works provides me with a } \\
\text { sense of accomplishment and this helps me be a } \\
\text { better family member }\end{array}$ & 0.93 & & \\
\hline
\end{tabular}


Table 2: (continued)

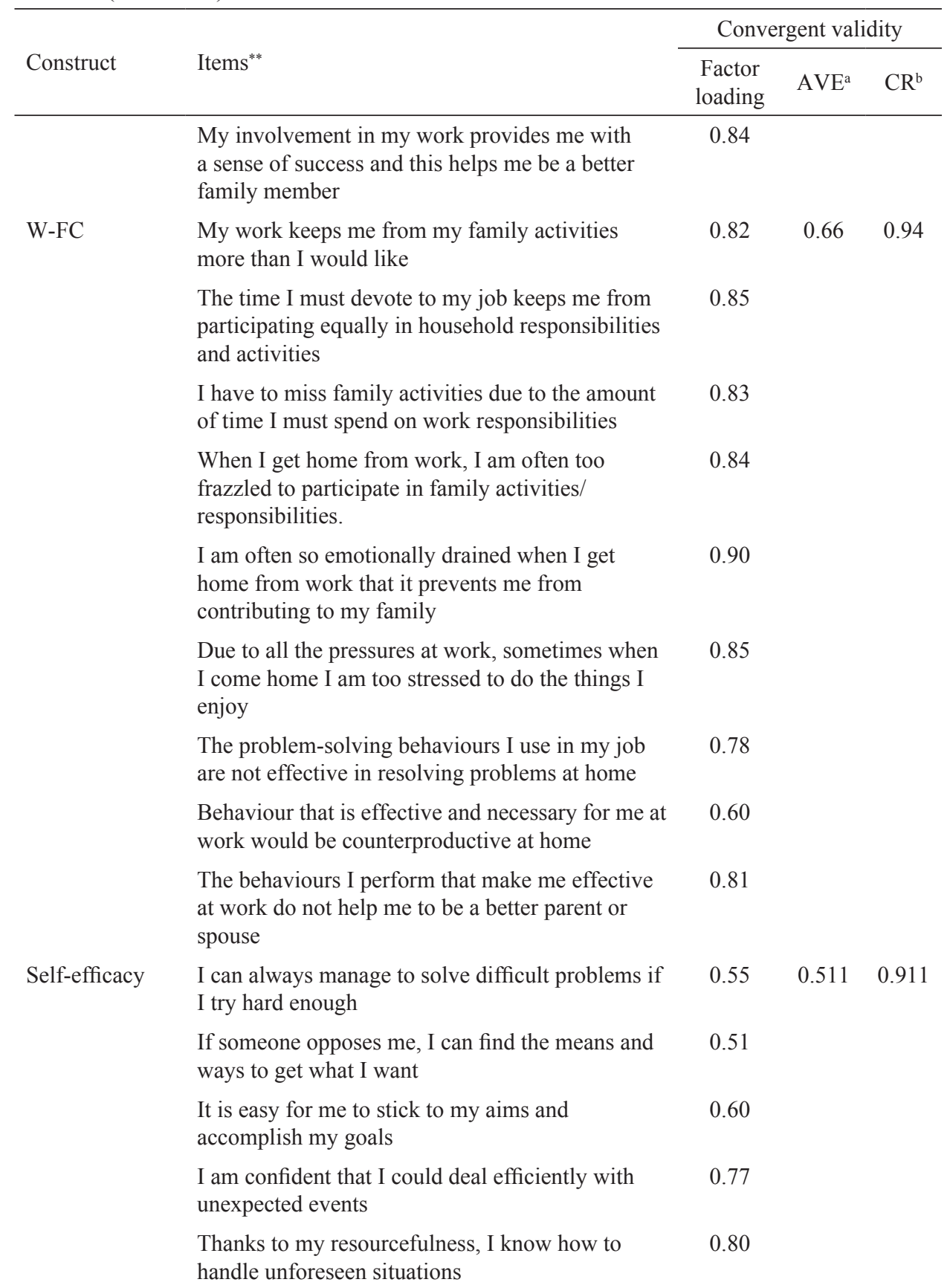


Table 2: (continued)

\begin{tabular}{llcl}
\hline \multirow{2}{*}{ Construct } & Items $^{* *}$ & \multicolumn{2}{c}{ Convergent validity } \\
\cline { 2 - 3 } & $\begin{array}{c}\text { Factor } \\
\text { loading }\end{array}$ & AVE $^{\mathrm{a}}$ & $\mathrm{CR}^{\mathrm{b}}$ \\
\hline & $\begin{array}{l}\text { I can solve most problems if I invest the necessary } \\
\text { effort }\end{array}$ & 0.71 \\
& $\begin{array}{l}\text { I can remain calm when facing difficulties } \\
\text { because I can rely on my coping abilities }\end{array}$ \\
& $\begin{array}{l}\text { When I am confronted with a problem, I can } \\
\text { usually find several solutions }\end{array}$ & 0.80 \\
& $\begin{array}{l}\text { If I am in trouble, I can usually think of a solution } \\
\text { I can usually handle whatever comes my way }\end{array}$ & 0.78 \\
\hline
\end{tabular}

Note: ${ }^{\text {a AVE }}=$ (Square of the summation of the factor loading)/(square of the summation of the factor loadings) + (square of the summation of the error variances); ${ }^{\mathrm{b}} \mathrm{CR}=$ (Summation of the square of the factor loadings)/ (summation of the square of the factor loadings) + (summation of the error variances); ${ }^{* *}$ only final items were listed

\section{Descriptive and Correlation Analysis}

The results in Table 3 indicated that the means for all the variables was moderate ranging from 2.906 until 3.985. The highest mean was job autonomy with 3.985 while the lowest mean was W-FC with 2.906. Standard deviations range from 0.473 to 0.762 where W-FC was the highest whereas self-efficacy was the lowest. Job autonomy has a significant positive moderate relationship with W-FE $(r=$ $0.503, p<0.001)$ and negative low relationship with W-FC $(r=-0.397, p<0.001)$ suggesting the increasing level of job autonomy increases the level of W-FE and reduces W-FC. Lastly, job autonomy was found to have a significant positive relationship with self-efficacy $(r=0.515, p<0.001)$. That is, a high level of job autonomy was related to the increasing level of self-efficacy.

Table 3

Intercorrelation between the variables

\begin{tabular}{lcccccccc}
\hline Variables & Mean & SD & Skewness & Kurtosis & JA & W-FE & W-FC & SE \\
\hline Job autonomy & 3.985 & 0.629 & -0.092 & 0.431 & - & $0.503^{* *}$ & $-0.397^{* *}$ & $0.515^{* *}$ \\
W-FE & 3.788 & 0.683 & -0.191 & -0.088 & $-0.503^{* *}$ & - & $-0.489^{* *}$ & $0.517^{* *}$ \\
W-FC & 2.906 & 0.762 & 0.132 & -0.505 & $-0.397^{* *}$ & $-0.489^{* *}$ & - & $-0.345^{* *}$ \\
Self-efficacy & 3.926 & 0.473 & -0.194 & 0.899 & $0.515^{* *}$ & $0.517^{* *}$ & $-0.345^{* *}$ & - \\
\hline
\end{tabular}

Note: JA = Job autonomy; W-FE = work-family enrichment; W-FC = work-family conflict; $\mathrm{SE}=$ self-efficacy; ${ }^{* *} p$ value $<0.005$ 


\section{Hypothesis Testing}

\section{Direct effects results}

The direct model of job autonomy towards work-life balance constructs was executed using two-level of latent modelling using AMOS. Overall, the model has yielded a good fit with $\chi^{2}(\mathrm{n}=307)=359.40, p<0.001, \chi^{2} / \mathrm{df}=1.97$, RMSEA $=$ $0.05, \mathrm{RMR}=0.08, \mathrm{CFI}=0.96, \mathrm{GFI}=0.90$. Result in Table 4 suggests that overall job autonomy explained the $40 \%$ variance of $\mathrm{W}-\mathrm{FE}$ and $25 \%$ variance of $\mathrm{W}-\mathrm{FC}$, respectively. The specific result indicates that job autonomy gives a significant impact on both W-FC and W-FE, thus accepting both $\mathrm{H}_{1}$ and $\mathrm{H}_{2}$. Job autonomy was found to positively influence W-FE $(\beta=0.643, p<0.001)$ and negatively influence W-FC $(\beta=-0.491, p<0.001)$.

Table 4

Result for job autonomy effects on work-life balance constructs

\begin{tabular}{lccc}
\hline Direct effects & $\mathrm{R}^{2}$ & Standard estimates & $p$-value \\
\hline W-FE & 0.40 & 0.643 & ${ }^{* * *}$ \\
W-FC & 0.25 & -0.491 & ${ }^{* * *}$ \\
\hline
\end{tabular}

Note: $\mathrm{W}-\mathrm{FE}=$ work-to-family enrichment; $\mathrm{W}-\mathrm{FC}=$ work-to-family conflict; ${ }^{* * *} p$ value $<0.001$

\section{Moderation result of self-efficacy}

We employed structural equation modelling using interaction analysis by calculating z scores and cross-product terms. Results in Table 5 revealed that selfefficacy was a significant moderator in the relationship between job autonomy and W-FE (interaction $\beta=0.105, p<0.05$ ). It was found that in the presence of high self-efficacy, the relationship between W-FE was high when self-efficacy was high compared when job autonomy was low. However, self-efficacy was found not significant in between job autonomy and W-FC. Therefore, from this result, only $\mathrm{H}_{3}$ was supported while $\mathrm{H}_{4}$ was not supported.

Table 5

Moderation result of self-efficacy

\begin{tabular}{lcccc}
\hline Constructs & $\mathrm{R}^{2}$ & Estimates & $\mathrm{SE}$ & $p$-value \\
\hline Outcome: W-FE & 0.304 & & & \\
Job autonomy & & 0.340 & 0.054 & ${ }^{* * *}$ \\
Self-efficacy & & 0.353 & 0.054 & ${ }^{* * *}$ \\
Interaction effects $(\mathrm{JA} \times \mathrm{SE})$ & & 0.105 & 0.040 & $0.025^{*}$ \\
\hline
\end{tabular}


Table 5: (continued)

\begin{tabular}{lcccc}
\hline Constructs & $\mathrm{R}^{2}$ & Estimates & $\mathrm{SE}$ & $p$-value \\
\hline Outcome: W-FC & 0.172 & & & \\
Job autonomy & & -0.203 & 0.057 & ${ }^{* * *}$ \\
Self-efficacy & & -0.062 & 0.057 & $\mathrm{~ns}$ \\
Interaction effects $(\mathrm{JA} \times \mathrm{SE})$ & & 0.018 & 0.052 & $\mathrm{~ns}$ \\
\hline
\end{tabular}

Note: $\mathrm{W}-\mathrm{FE}=$ work-to-family enrichment; $\mathrm{W}-\mathrm{FC}=$ work-to-family conflict; $\mathrm{SE}=$ standard error; ${ }^{*} p$ value $<0.05$; ${ }^{* * *} p<0.001 ;$ ns $=$ not significant.

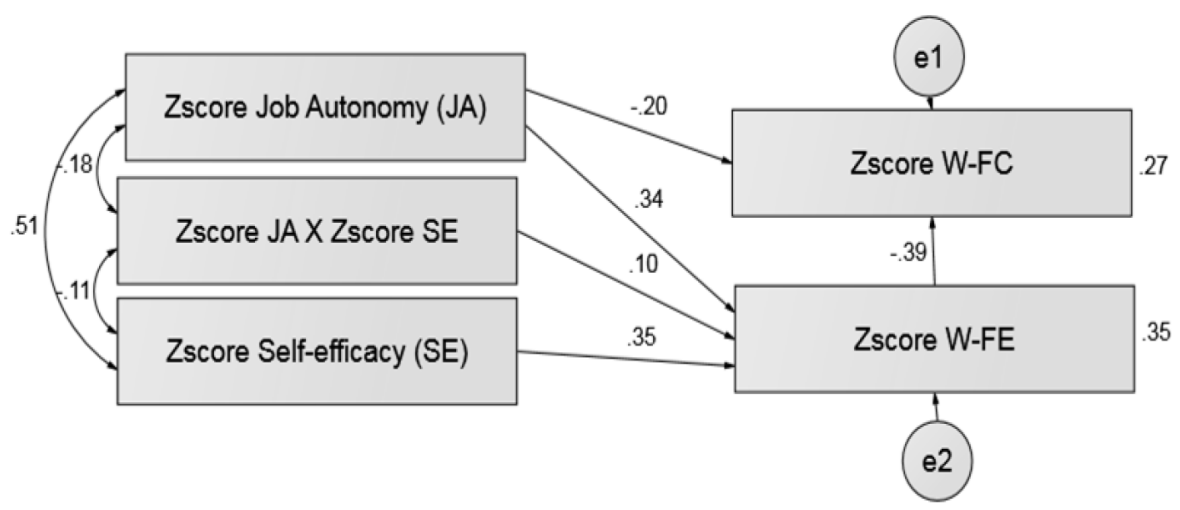

Figure 2. Moderation model of self-efficacy

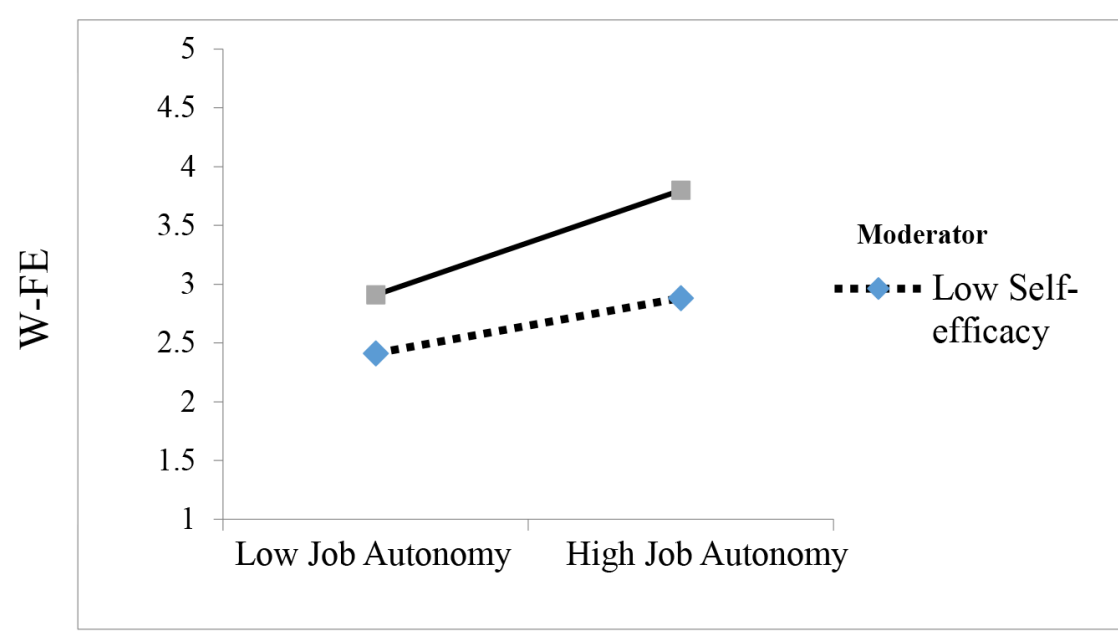

Figure 3. Moderation plot for moderation effects of self-efficacy in the relationship between job autonomy and W-FE 


\section{DISCUSSION}

This study found that higher job autonomy improves academic work-life balance through promoting of between domains enrichment (W-FE) and lowering of domains conflict (W-FC). In line with prior findings (Marais et al., 2014; Beutell, 2013), higher job autonomy in this study, likewise, helped academics to effectively manage their work and family responsibilities. Job autonomy has been deliberated in the past as an important work resource that can help employees to thrive in their work setting (Hill et al., 2008). Parallel to the other findings, this study endorsed that high job autonomy acted as an important resource for the academics to effectively manage varying demands from work and family responsibilities, hence improving their overall condition of work-life balance. In this study, we found that job autonomy does not only prove to foster a good balance between work and family domains but also helpful in reducing the occurrence of inter-roles conflict between work and family (Lee-Peng et al., 2013).

A higher level of job autonomy enables academics to fulfil the competing demands of both work and personal life. The provision of job autonomy offers flexibility in the ways and time of work, thus providing a greater opportunity and more room for the employee to balance their needs and juggle different aspects of life (Marais et al., 2014). Having a good control is also crucial for achieving a good degree of subjective life experience, in which, past research works have highlighted emotion and satisfaction as among essential elements to promote a balanced work and life (Kelly et al., 2011). Such a job attribute is similarly helpful to increase functionality among the dual-earner couple to maintain a high degree of parental involvement and children support which has been proven in the past as crucial aspect to achieve a better work and life (Christensen, 2013). Otherwise, for those with a single status, higher job autonomy means more opportunity to practice healthy and productive work and life.

Correspondingly, this study endorses the positive influence of individual attribute which is self-efficacy to further improve work-life balance condition. This affirms self-efficacy as a resourceful individual disposition which can increase the likelihood to achieve greater work-life balance. Based on our finding, those with a higher level of self-efficacy has a greater positive work and life experiences in the form of high work-family enrichment. As those with high self-efficacy has better control over their thoughts and action, therefore, it helps them to better cope within a challenging environment (Schunk, 1995; Zimmerman et al., 1992). The constructive belief derived from self-efficacy helps individual to maintain a positive mindset and self-control, thus further improving the degree of enrichment between work and family aspects. Such a positive mindset helps individual to 
establish a clearer goal-orientation in juggling work and family responsibilities. In another point of view, it is also plausible job autonomy may contribute to a greater sense of self-efficacy. Although we do not study this relationship in this paper, however, evidence has been suggesting that job autonomy increases self-efficacy level in the past (Skaalvik \& Skaalvik, 2014). As such, high control over work, likewise might promote high self-control which in turn improving academics' work-life balance ailment.

\section{CONCLUSION}

As more challenges existed within the higher education setting, acquiring control both in the job and individual aspects are vital for academics' population. Changing landscape, rising workload, demanding students, and shifting of teaching practice are among few from many things that can heighten the risk of work-life imbalance among this occupational group. Therefore, ensuring the autonomous working environment is crucial to help academics carefully monitor their pace and ways of working in fulfilling both work and family responsibilities.

\section{Implications}

\section{Theoretical implications}

There are several implications from this paper. First, it adds to recent empirical evidence on the role of job autonomy and self-efficacy towards academics' work-life balance. Findings from this paper would be beneficial to further assist HEIs, future researchers, and academics themselves to have a clear understanding regarding the role of both job and individual characteristics, in particular work autonomy and self-efficacy, in affecting the dynamics of work and family-life balance among academics' population. Second, this paper contributes to developing a greater theoretical understanding regarding the effect of a dispositional characteristic such as self-efficacy in further improving academics' work-life balance condition. This study confirmed the theoretical relevance of considering the ability to exert selfcontrol as an alternative aspect to understand academics' work-life balance which has been often underemphasised in past research.

\section{Practical implications}

Besides, findings from this paper serve as a useful platform to inform relevant authorities, researchers or HEIs to endorsing a good work policy or strengthening the existing policy related to the given autonomy at work. As job autonomy found 
to reduce inter-roles conflict and improving enrichment between work and family domains, therefore, giving more opportunity for academic to take control over the various aspects of their job should be largely considered in future. Other than that, any planning on future intervention or training should take account the importance of dispositional element such as self-efficacy to further promote and develop better work-life balance practice or policies.

\section{Suggestion and Limitations}

This study, likewise others, is not without limitations. As we rely on the selfreported questionnaire to gather the data, it can be subjected to self-report bias. Therefore, future researchers might want to expand to other methodologies such as a qualitative method to develop a more in-depth understanding and explanation on how job autonomy influences academics' work-life balance. It is also worthy to conduct this study with a more robust design by using mixed-method or longitudinal to overcome the limitation of causal inferences and observe if there are any behavioural changes which may occur over time. Particularly interesting is to investigate how job autonomy is defined in terms of working hour, amount of teaching, research workload, administrative role, or any others to gain a more accurate understanding on this subject. Any future research would want to also consider expanding to other range of job characteristics which existed in HEIs such as variation of the task or individual dispositional trait to further discuss this topic. Lastly, since this study was conducted among academics' population, therefore, the result could only be generalised towards similar population and less appropriate to be used in a different setting.

\section{REFERENCES}

Achour, M. \& Boerhannoeddin, A. (2011). The role of religiosity as a coping strategy in coping with work-family conflict: The case of Malaysia women in academia. International Journal of Social Science and Humanity, 1(1), 80-85.

Badri, S.K.Z. (2019). Affective well-being in the higher education sector: Connecting of work-life balance with mental health, job satisfaction and turnover issues inside the academic setting, International Journal of Happiness and Development, 5(3), 225-241.

Baillien, E., Cuyper, N.D., \& De Witte, H. (2011). Job autonomy and workload as antecedents of workplace bullying: A two-wave test of Karasek's Job Demand Control Model for targets and perpetrators. Journal of Occupational and Organisational Psychology, 84, 191-208.

Ballout, H.I. (2009). Career commitment and career success: Moderating role of selfefficacy. Career Development International, 14(7), 655-670. 
Bandura, A. (1982). Self-efficacy mechanism in human agency. American Psychologist, $37(2), 122-147$.

Bandura, A. (1997). Self-efficacy: The exercise of control. Freeman.

Bandura, A. (2010). Self-efficacy. In I.B. Weiner \& W.E. Craighead (eds.), The Corsini encyclopedia of psychology (p. 1534). John Wiley \& Sons.

Barbaranelli, C., Paciello, M., Biagioli, V., Fida, R., \& Tramontano, C. (2019). Positivity and behaviour: The mediating role of self-efficacy in organisational and educational setting. Journal of Happiness Studies, 20, 707-727.

Beuregard, T.A. \& Henry, L.C. (2009). Making the link between work-life balance practices and organisational performances. Human Resource Management Review, 29, 9-22.

Beutell, N.J. (2013). Generational differences in work-family conflict and synergy. International Journal of Environmental Research and Public Health, 10, 25442559.

Brown, S.P., Ganesan, S., \& Challagalla, G. (2001). Self-efficacy as a moderator of information-seeking effectiveness. Journal of Applied Psychology, 86(5), 10431051.

Carlson, D.S., Kacmar, M.K, Wayne, J.H., \& Grzywacz, J.G. (2006). Measuring the positive side of the work-family interface: Development and validation of a workfamily enrichment scale. Journal of Vocational Behavior, 68(1), 131-164.

Carlson, D.S., Kacmar, K.M., \& Williams, L.J. (2000). Construction and initial validation of a multidimensional measure of work-family conflict. Journal of Vocational Behavior, 2(56), 249-276.

Choi, E. \& Kim, J. (2017). The association between work-life balance and health status among Korean workers. Journal of Prevention, Assessment \& Rehabilitation, $58(4), 509-517$.

Christensen, K. (2013). Launching the workplace flexibility movement: Work family research and a program of social change. Community, Work and Family, 16(3), 261-284.

Clarke, M., Kenny, A., \& Loxley, A. (2015). Creating a supportive working environment for academics in higher education. Country report, Ireland, Irish Federation of University Teachers and Teachers' Union of Ireland.

Crompton, R. \& Lyonette, C. (2006). Work-life "balance" in Europe. Acta sociologica, 49(4), 379-393.

Cretu, R.Z. \& Burcas, S. (2014). Self-efficacy: A moderator of the relation between emotional dissonance and counterproductive work behaviour. Procedia-Social and Behavioural Sciences, 127(22), 892-896.

De Jonge, V. \& Schaufeli, W.B. (1999). Job characteristics and employee well-being: A test of Warr's Vitamin Model in health care workers using structural equation modelling. Journal of Organisational Behaviour, 19(4), 387-407.

Einar, M.S. \& Sidsel, S. (2010). Teacher self-efficacy and teacher burnout: A study of relations. Teaching and Teacher Education, 26(4), 1059-1069.

Fitzgerald, S. \& Schutee, N. S. (2010). Transformational leadership through enhancing self-efficacy. Journal of Management Development, 29(5), 495-505. 
Frederick, P.M., Delaney-Klinger, K., \& Hemingway, M.A. (2005). The importance of job autonomy, cognitive ability and job-related skill for predicting role breadth and job performance. Journal of Applied Psychology, 90(2), 399-406.

Friedman, S.D. \& Greenhaus, J.H. (2000). Work and family - Allies or enemies? What happens when business professionals confront life choices. Oxford University Press.

Grau, R., Salanova, M., \& Peiró, J.M. (2001). Moderator effects of self-efficacy on occupational stress. Psychology in Spain, 5(1), 63-74.

Greenhaus, J.H. \& Beutell, N.J. (1985). Sources of conflict between work and family roles. Acedemy of Managememnt Review, 10, 76-88.

Greenhaus, J.H. \& Powell, G.N. (2006). When work and family are allies: A theory of work-family enrichment. The Academy of Management Review, 31(1), 72-92.

Grotto, A.R. \& Lyness, K.S. (2010). The costs of today's jobs: Job characteristics and organisational supports as antecedents of negative spillover. Journal of Vacational Behavior, 76, 395-405.

Grover, S.L. \& Crooker, K.J. (1995). Who appreciates family-responsive human resource policies: The impact of family-friendly policies on the organizational attachment of parents and non-parents. Personnel Psychology, 48, 271-288.

Guarnaccia, C., Scrima, F., Civilleri, A., \& Salerno, L. (2018). The role of occupational self-efficacy in mediating the effect of job insecurity on work engagement, satisfaction and general health. Current Psychology, 37(3), 488-497.

Haar, R., Russo, M., Sune, A., \& Ollier-Malaterre, A. (2014). Outcomes of work-life balance on job satisfaction, life satisfaction and mental health: A study across seven cultures. Journal of Vocational Behavior, 85(3), 361-373.

Haar, J., Sune, M., Russo, A., \& Ollier-Malaterre, M. (2019). A cross-national study on the antecedents of work-life balance from the fit and balance perspective. Social Indicators Research, 142(1), 261-282.

Hackman, J.R. \& Oldham, G.R. (1980). Work redesign. Addison-Wesley.

Hair, J.F., Black, B., Babin, B., Anderson, R.E., \& Tatham, R.L. (2010). Multivariate data analysis: A global perspective. Pearson.

Hill, E.J., Grzywacz, J.G., Allen, S., Blanchard, V.L., Matz-Costa, C., Shulkin, S., \& Pitt-Catsouphes, M. (2008). Defining and conceptualizing workplace flexibility. Community, Work and Family, 11(2), 149-163.

Hobfoll, S. (1989). Conservation of resources: A new attempt at conceptualizing stress. The American Psychologist, 44(3), 513-524.

Hobfoll, S. E., Halbesleben, J., Neveu, J-P., \& Westman, M. (2018). Conservation of resources in the organisational context: The reality of resources and their consequences. Annual Review of Organisational Psychology and Organisational Behaviour, 5, 103-28

Hogan, M. (2015). Work hours, work-life conflict and well-being in academics. PsychologyToday.com. https://www.psychologytoday.com/blog/in-onelifespan/201504/work-hours-work-life-conflict-and-well-being-in-academics.

Husin, N.A., Ghazali, A.S.M., Abudullah, N., \& Hadi, I.A. (2018). Work-life balance of Malaysian lecturers. Australian Academy of Business and Economics Reviews, 4(1), 43-49. 
Kelly, E.L., Moen, P., \& Tranby, E. (2011). Changing workplaces to reduce work-family conflict: Schedule control in a white-collar organisation. American Sociological Review, 76(2), 265-290.

Kinman, G. \& Jones, F. (2008). A life beyond work?Job demands, work-life balance, and well-being in UK Academics. Journal of Human Behaviour in the Social Environment, 17(1-2), 41-60.

Klassen, R.M. \& Chiu, M.M. (2010). Effects on teachers' self-efficacy and job satisfaction: Teacher gender, years of experience, and job stress. Journal of Educational Psychology, 102(3), 741-756.

Kubicek, B., Paskvan, M., \& Bunner, J. (2017). The bright and dark sides of job autonomy. In C. Korunka \& B. Kubicek (eds), Job demands in a changing world of work (pp. 45-63). Springer.

Le, H., Newman, A., Menzies, J., Zheng, C., \& Fermelis, J. (2020). Work-life balance in Asia: A systematic review. Human Resource Management Review, 30(4), 100766. https://doi.org/10.1016/j.hrmr.2020.100766

Lee-Peng, N., Lok-Sin, K., \& Ka-Fei, L. (2013, June). The impact of job demands, supervisor support and job control on work-to-personal life conflict among the employed workers [paper presentation]. International Conference on Social Science Research, ICSSR 2013, Penang, Malaysia.

Li, H., Li, F. \& Chen, T. (2018). A motivational-cognitive model of creativity and the role of autonomy. Journal of Business Research, 92, 179-188.

Lingard, H., Brown, K., Bradley, L., Bailey, C., \& Townsend, K. (2007). Improving employees' work-life balance in construction industry: Project alliance case study. Journal of Construction Engineering and Management, 133(10), 807-815.

Lyons, M. \& Ingersoll, L. (2010). Regulated autonomy or autonomous regulation? Collective bargaining and academic workloads in Australian universities. Journal of Higher Education Policy and Management, 32(2), 137-148.

Marais, E., De Klerk, M., Nel, J.A., \& De Beer, L. (2014). The antecedents and outcomes of work-family enrichment amongst female workers. SA Journal of Industrial Psychology, 40(1). https://doi.org/10.4102/sajip.v40i1.1186

Mellner, C., Aronsson, G., \& Kecklund, G. (2015). Boundary management preferences, boundary control, and work-life balance among full-time employed professionals in knowledge-intensive, flexible work. Nordic Journal of Working Life Studies, 4(4), 7-23.

Mohamadi, F.S. \& Hassan, A. (2012). Testing the mediating role of teachers' self-efficacy beliefs in the relationship between sources of efficacy information and students achievement. Asia Pacific Education Review, 13(3), 427-423.

Morgeson, F.P., Delaney-Klinger, K., \& Hemingway, M.A. (2005). The importance of job autonomy, cognitive ability, and job-related skill for predicting role breadth and job performance. Journal of Applied Psychology, 90(2), 399-406.

Nasurdin, A.M. \& O’Driscoll, M.P (2011). Work overload, parental demand, perceived organisational support, family support, and work-family conflict among New Zealand and Malaysian academics. New Zealand Journal of Psychology, 40(3), $38-48$. 
Nauta, M., Liu, C., \& Li, C. (2010). A cross-national examination of self-efficacy as a moderator of autonomy/job strain relationships. Applied Psychology, 59(1), 159179.

Ng, L-P., Chen, I-C., Ng, H-F., Lin, B-Y., \& Kuar, L-S. (2017). Influence of job demands and job control on work-life balance among Taiwanese nurses. Journal of Nursing Management, 25(6), 438-448.

Noor, K.M. (2011). Work-life balance and intention to leave among academics in Malaysian public Higher education institutions. International Journal of Business and Social Sciences, 2(11), 240-248.

Nunnally, J.C. (1978). Psychometric theory. McGraw-Hill.

O’Neill, B.S. \& Mone, M.A. (1998). Investigating equity sensitivity as a moderator of relations between self-efficacy and workplace attitudes. Journal of Applied Psychology, 83(5), 805-816.

Panatik, S.A., Rajab, A., Shah, M.D., Rahman, H.A., Yusoff, R.M., \& Badri, S.K.Z. (2012). Work-family conflict, stress and psychological strain in higher education. IEPDR, 30, 67-71.

Parker, S.H., Axtell, C.M., \& Turner, N. (2001). Designing a safer workplace: Importance of job autonomy, communication quality, and supportive supervisors. Journal of Occupational Health Psychology, 6(3), 211-228.

Proost, K., De Witte, H., De Witte, K., \& Schereurs, B. (2010). Work-family conflict and facilitation: The combined influence of the job demand-control model and achievement striving. European Journal of Work and Organisational Psychology, 19(5), 615-628.

Reddy, N.K., Vranda, M.N., Ahmed, A., Nirmala, B.P., \& Siddaramu, B. (2010). Worklife balance among married women employees. Indian Journal of Psychological Medicine, 32(2), 112-118.

Richman, A.L., Civian, J.T., Shannon, L.L., Hill, E.J., \& Brennan, R.T. (2008). The relationship of perceived flexibility, supportive work-life policies, and use of formal flexible arrangements and occasional flexibility to employee engagement and expected retention. Community, Work and Family, 11(2), 183-197.

Schunk, D.H. (1995). Self-efficacy, motivation, and performance. Journal of Applied Sport Psychology, 7(2), 112-137.

Schwarzer, R. (ed.). (1992). Self-efficacy. Taylor \& Francis.

Schwarzer, R. \& Jerusalem, M. (1995). Generalized self-efficacy scale. In J. Weinman, S. Wright, \& M. Johnston (eds.), Measures in health psychology: A user's portfolio. Causal and control beliefs (pp. 35-37). NFER-Nelson.

Sisodia, S. \& Das, I. (2013). Effect of job autonomy upon organisational commitment of employees at different hierarchical level. Psychical Thought, 6(2), 241-251.

Skaalvik, E.M. \& Skaalvik, S. (2014). Teacher self-efficacy and perceived autonomy: Relations with teacher engagement, job satisfaction, and emotional exhaustion. Psychological Reports, 114(1), 68-77.

Sogolitapeh, F.M. \& Razmi. S. (2011). The moderating role of self-efficacy in relationship between occupational stress with psychological health and job satisfaction of saderat bank's staffs of Tabriz. Iran Occupational Health Journal, 8(2), 57-65. 
Tement, S. \& Korunka, C. (2015). The moderating impact of types of caregiving on job demands, resources, and their relation to work-to-family conflict and enrichment. Journal of Family Issues, 36, 31-55.

Wheately, K.F. (2005). The case for conceptualizing teacher efficacy research. Teaching and Teacher Education, 21, 747-766.

Wood, R.E. \& Marshall, V. (2008). Accuracy and effectiveness in appraisal outcomes: The influence of self-efficacy, personal factors and organisational variables. Human Resource Management Journal, 18(3) 295-313.

Zimmerman B.J., Bandura, A., \& Martinez-Pons, M. (1992). Self-motivation for academic attainment: The role of self-efficacy beliefs and personal goal setting. American Educational Research Journal, 26, 663-676. 